\title{
The Influence of Experience on the Farmers' Attitudes in Utilizing Integrated Rice Agricultural Services Center (SP3T)
}

\author{
Pradite Nimas Ayu Astardiana ${ }^{1}$, Suminah ${ }^{2}$, Sugiharjo ${ }^{3}$ \\ ${ }^{1,2,3}$ Postgraduate Development Extension Study Program, Sebelas Maret University, \\ Indonesia \\ Email:praditeayu866@gmail.com
}

\begin{abstract}
Farmers need facilities to support agricultural productivity. The government provides agricultural equipment assistance to the success of the program to increase production, productivity and quality of food crops in the form of Integrated Rice Agriculture Service Centers (Sentra Pelayanan Pertanian Padi Terpadu/SP3T). One of the facilities provided in the program to increase the production, productivity and quality of food crops is the SP3T sub-program in which the facilities provided are more focused on post-harvest tools and production facilities. Central Java Province and 33 other provinces were given the opportunity to run the SP3T sub-program. Central Java is a province that has the highest rice production in 2019. This study aims to determine the effect of personal experience on farmers' attitudes in using Integrated SP3T. Sampling was purposive as many as 75 people. The basic method of research is descriptive quantitative. The data used are primary and secondary data. The data analysis used is simple linear regression. The results showed that there was a significant effect $(p=0.001)$ between personal experience and farmer attitudes.
\end{abstract}

Keywords: Facilities, Rice, Experience, Farmers, Attitudes.

\section{A. INTRODUCTION}

Farmers need agricultural facilities to support agricultural productivity. The government provides agricultural equipment assistance to the success of the program to increase production, productivity and quality of food crops. The government aid budget allocation is used to facilitate farmer groups and aid recipients to cultivate rice, corn and soybeans. One of the facilities provided in the program to increase the production, productivity and quality of food crops is the SP3T sub-program where the facilities provided are more focused on post-harvest tools and production facilities. Central Java Province and 33 other provinces were given the opportunity to run the sub-program for integrated rice agriculture service centers (Sentra Pelayanan Pertanian Padi Terpadu/SP3T).

Central Java was the province with the highest rice production in 2019. The positive attitude of farmers towards a government program is important because attitudes can determine the success of a sub-program such as SP3T. The positive attitude of farmers can be influenced by other people who are considered important. Gerungan (1988) states that attitudes are always accompanied by a tendency to act on objects. Farmers have not fully utilized the facilities of aSP3T. It can be seen that farmers are still selling their agricultural products to middlemen, where the aim of 
the SP3T program is to break the chain of selling their crops to middlemen. The purpose of this study was to examine the effect of personal experience on farmers' attitudes directly on the use of SP3T in Sukoharjo and Karanganyar Districts.

Attitude as a response. The response will only arise when the individual is faced with a stimulus which requires an individual reaction. Attitude structure consists of three components that support each other, namely cognitive, affective, and conative components (Azwar, 2003). Meanwhile, according to Simamora (2002) that in attitude there are three components, namely 1) Cognitive component: consumer confidence and knowledge of objects. Objects are product attributes, the more positive the trust in a product brand, the overall cognitive components will support the overall attitude. 2) Affective component: emotional that reflects a person's feelings on an object, whether the object is wanted or liked. 3) Behavioral component: reflects the actual tendency and behavior towards an object, where this component shows the tendency to perform an action. Azwar (2003) states that one of the factors that influence attitude formation is other people who are considered important. Individuals will behave in the same direction as the attitudes of the people they consider important. This tendency is motivated, among other things, by the desire to avoid conflict with people who are considered important.

Attitude is a reaction or response that is still closed from someone to a stimulus or object. The manifestation of attitude cannot be seen immediately, but can only be interpreted first from closed behavior. Attitude is still a closed reaction, not an open reaction or open behavior (Wawan, 2011).

The Sentra Pelayanan Pertanian Padi Terpadu/SP3T (Integrated Rice Agricultural Service Center) program will begin with the stages of land processing, extension, seeding, planting to the stage of harvesting and milling grain. The Ministry of Agriculture of the Republic of Indonesia is working with the Kodim to realize the Integrated Rice Farmers Service Center Program. This program aims to improve the yield and quality of farmers' rice harvests and food self-sufficiency, so that Sukoharjo district can become an independent rice granary center in an effort to improve the welfare of the farming community.

\section{B. METHOD}

This research was conducted using quantitative research methods. Quantitative research focuses on collecting data in the form of numbers to be analyzed using quantitative analysis tools and mathematical calculations. This research uses survey technique. The research was conducted by taking samples from a population using a questionnaire as a means of collecting data on a particular problem in a certain area. Determination of the research location is done purposively (purposive), which is based on certain considerations tailored to the research objectives (Singarimbun \& Effendi, 1995). Determination of the sample that can be used is by means of simple random sampling. Simple Random Sampling is a sample taken randomly or randomly from all populations. The population was taken as 
many as 75 people with a non-probability sampling method. The analysis used is simple linear regression analysis, with the equation:

$\mathrm{Y}=\mathrm{a}+\mathrm{bX}+\mathrm{e}$.

Explanation:

Y : The Attitude of the Farmer

a : Constant

$\mathrm{b}:$ Regression Coefficient

$X$ : Personal Experience

E : Standard Error

\section{RESULT AND DISCUSSION}

The influence of personal experience on farmer attitudes can be seen in table 1 below:

Table 1 Analysis of the Influence of Personal Experience on Farmer Attitudes

\begin{tabular}{cccc}
\hline Description & Sign & $\alpha$ & Explanation \\
\hline Personal experience & 0,001 & 0,05 & Significant \\
\hline
\end{tabular}

Source: Primary Data Analysis (2020)

Based on table 1 it can be seen that there is an influence between personal experience $(\mathrm{p}=0.050 \leq \alpha=0.001)$ on farmer attitudes. The size of the farmer's attitude is influenced by experience. The more experience, the better the attitude of the farmers in utilizing the Integrated Rice Agriculture Service Center (SP3T). Increasingly experience a peasant farming increasingly bold in taking risks to try. Experience allows farmers to see all the opportunities and obstacles that will be faced in farming.

Farmers have the same experience between the SP3T program and the previous program. With the existence of the same program, it is easier for farmers to understand the program that has just been provided by the government. Farmers easily recognize the SP3T program, that is, farmers can use agricultural tools skillfully. Farmers' knowledge about the SP3T program is also good. Farmers' knowledge includes understanding of program names, program objectives, program implementation and results of the SP3T program. Many farmers 'experiences and similar to the new program provided by the government can shape farmers' attitudes for the better. The attitude of farmers towards the SP3T program is positive farmers welcome it well with the program because the SP3T program can make it easier for farmers to do farming.

Attitudes will be more easily formed when personal experiences occur in situations that involve emotional factors. In situations involving emotions, the appreciation will be deeper and last longer. Furthermore, Mardikanto (1996) states that the experience in carrying out farming activities is reflected in the habits they (farmers) apply in farming activities and are the results of learning from their experiences. What we experience will shape and influence our appreciation of social stimuli. Responses will be one of the bases for forming attitudes. To be able to be the 
basis for the formation of attitudes, personal experiences must go through a strong impression (Azwar, 1991).

Farmers learn a lot from their own experiences and the experiences of others about a technological innovation by trying a variety of actions. The level of action taken by the farmer depends on the level of benefits and benefits to be received. A farmer with low education is often apathetic towards innovation as a result of failures he has experienced in the past, due to a lack of knowledge about innovation.

Attitudes will be more easily formed if these personal experiences involve emotional factors. In situations that involve emotions, the appreciation of the experience will be deeper and last longer (Azwar, 2003). Middlebrook (1974) states that the absence of experience at all with a psychological object tends to form a negative attitude towards the object on the contrary the experience tends to form a positive attitude towards an object. The higher a person's experience of an object, the higher the tendency to take advantage of that object, and the greater the expectation for obtaining these benefits.

Attitudes will not respond directly to a change, realizing that knowledge and attitudes are influenced by experience (Rambe \& Honorita, 2011). Purwanto (2005) said that experience can also shape attitudes as a process of increasing the knowledge possessed by farmers including the experience of using new technology. Knowledge is the initial stage in the occurrence of perception which then gives birth to attitudes and in turn gives birth to actions or actions. Experience has shown that the interactions that occur tend to result in a reciprocal self and skill adjustments to new situations.

$\mathrm{Vu}$ et al., (2020), their experience had a strong impact on other farmers' behavior, as the similarity between important referents and target persons was demonstrated to improve the persuasiveness of the information given.

Attitudes are considered as a central concept of social psychology (Ajzen, 2005). All port in Hammes et al., (2016) defined an attitude as "a mental and neural state of readiness, organized through experience, exerting a directive and dynamic influence upon the individual's response to all objects and situations with which it is related". Later the concept of attitudes was mainly reduced to its evaluative component.

Ben Yishay \& Mobarak (2018), emphasized that peer farmers who had similar agricultural conditions to the target farmers were significant referents to transfer new technologies in rural communities. Therefore, sharing the experience of peer farmers applying organic fertilizer has the potential to affect other farmers' behavior in adopting organic fertilizer.

An attitude is an expression of favor or disfavor toward a person, place, practice, or event (O'Leary et al., 2018). A belief, or conviction, is a psychological state where someone holds a specific premise to be true or not. As they are closely related concepts, attitudes and beliefs as well as objectives and goals will henceforth be referred to together as "attitudes". Behaviors relate to a person's response to particular situations or stimulus (Jones et al., 2016). The relationships between 
farmers' attitudes toward mandatory agricultural water saving polices and demographic variables age, education, sex and experience as a floating worker have also been analyzed (Chang, 2016).

Well-established occupational-psychology literature has demonstrated strong and consistent associations between employee (including managers) attributes and job performance (e.g., Hunter \& Hunter, 1984; O’Boyle et al., 2011). Application of such insight in agriculture, however, would benefit from further research in an agricultural context. Confirming that the associations found in general occupational psychology studies exist in different groups of farmers, and how best to apply these insights effectively, would be valuable.

Self-identity and attitudes, while similar, represent different constructs. For this study attitude is defined as an expression, belief or evaluation of something specific such as a person, event or thing (Sulemana \& James, 2014). By comparison self-identity is removed from situational demands (Burke, 2008) and represents the salient and enduring aspects of the perception of oneself in their role (Rise et al., 2010). This forms identity standards that guide behavior relating to that role (Stets and Burke, 2003).

Learning is acquiring and improving the ability to carry out a pattern of attitudes through experience and practice (Van den Ban and Hawkins, 2000). Between knowledge, attitudes, personality and behavior are interrelated factors that direct individuals to carry out a business that is beneficial to their life and future.

Attitude traits can be divided into positive attitudes (the tendency for action is to approach, like, expect certain objects) and negative (tendencies to stay away, avoid, hate, dislike certain objects) (Wawan, 2011). The attitude of farmers in using the SP3T tool is a positive one. Farmers enthusiastically welcomed the program.

\section{CONCLUSION}

Based on the results of the research that has been done, it can be concluded that personal experience affects farmers' attitudes in utilizing Integrated Rice Agriculture Service Centers (SP3T). Farmers easily recognize the SP3T program, that is, farmers can use agricultural tools skillfully. Farmers' knowledge about the SP3T program is also good. Farmers' knowledge includes understanding of program names, program objectives, program implementation and results of the SP3T program. Many farmers 'experiences and similar to the new program provided by the government can shape farmers' attitudes for the better.

\section{REFERENCES}

1. Ajzen, I., (2005). Attitudes, Personality and Behavior. New York: Open University Press.

2. Azwar, S. (2003). Sikap Manusia: Teori dan Pengukurannya. Yogyakarta: Pustaka Pelajar. 
3. BenYishay, A., \& Mobarak, A. M. (2019). Social learning and incentives for experimentation and communication. The Review of Economic Studies, 86(3), 9761009.

4. Burke, P. J. (1980). The self: Measurement requirements from an interactionist perspective. Social Psychology Quarterly, 18-29.

5. Chang, G., Wang, L., Meng, L., \& Zhang, W. (2016). Farmers' attitudes toward mandatory water-saving policies: A case study in two basins in northwest China. Journal of Environmental Management, 181, 455-464.

6. Gerungan, W. A. (1988). Psikologi Sosial. Bandung: Refika Aditama.

7. Hammes, V., Eggers, M., Isselstein, J., \& Kayser, M. (2016). The attitude of grassland farmers towards nature conservation and agri-environment measures-A survey-based analysis. Land Use Policy, 59, 528-535.

8. Hunter, J. E., \& Hunter, R. F. (1984). Validity and utility of alternative predictors of job performance. Psychological bulletin, 96(1), 72.

9. Jones, P. J., Sok, J., Tranter, R. B., Blanco-Penedo, I., Fall, N., Fourichon, C., ... \& Sundrum, A. (2016). Assessing and understanding, European organic dairy farmers' intentions to improve herd health. Preventive Veterinary Medicine, 133, 84-96.

10. Mardikanto, T. (1993). Penyuluhan Pembangunan Pertanian. Surakarta: Sebelas Maret University Press.

11. Middlebrook. (1974). Social Psychology and Modern Life. New York. Alfred: A. Knop. Inc.

12. O'Boyle Jr, E. H., Humphrey, R. H., Pollack, J. M., Hawver, T. H., \& Story, P. A. (2011). The Relation between Emotional Intelligence and Job Performance: A Meta-Analysis. Journal of Organizational Behavior, 32(5), 788-818.

13. O'Leary, N. W., Bennett, R. M., Tranter, R. B., \& Jones, P. J. (2018). The extent that certain dairy farmer attitudes and behaviors are associated with farm business profitability. Journal of Dairy Science, 101(12), 11275-11284.

14. Purwanto. (2005). Tujuan Pendidikan dan Hasil Belajar. Jakarta: Jurnal Teknodik Depdiknas.

15. Rambe, S. S. \& Honorita, B. (2011). Perilaku petani dalam usahatani padi di lahan rawa lebak. Prosiding Seminar Nasional Budidaya Pertanian, Urgensi dan Strategi, Pengendalian Alih Fungsi lahan Pertanian. Bengkulu: Balai Pengkajian Teknologi Pertanian Bengkulu.

16. Rise, J., Sheeran, P., \& Hukkelberg, S. (2010). The Role of Self-Identity in the Theory of Planned Behavior: A Meta-Analysis. Journal of Applied Social Psychology, 40(5), 1085-1105.

17. Simamora, H. (2002). Sumber Daya Manusia. Yogyakarta: STIE YKPN.

18. Stets, J. E., \& Burke, P. J. (2003). A sociological approach to self and identity. Handbook of Self and Identity, 128152.

19. Sulemana, I., \& James Jr., H. S. (2014). Farmer identity, ethical attitudes and environmental practices. Ecological Economics, 98, 49-61. 
20. Van den Ban, A., W., \& Hawkin, H. S. (2000). Penyuluhan Pertanian. Yogyakarta: Kanisius.

21. Vu, H. T., Tran, D., Goto, D., \& Kawata, K. (2020). Does experience sharing affect farmers' pro-environmental behavior? A randomized controlled trial in Vietnam. World Development, 136, 105062.

22. Wawan. (2011). Pengetahuan Sikap dan Perilaku Manusia. Yogyakarta: Nuha Medika. 